\title{
Psychiatric experience with perpetrators and countertransference feelings in the therapist
}

\author{
J Lansen on behalf of the Fohannes Wier Foundation for Human Rights and Health Care, The Netherlands
}

Therapeutic work on man-made disaster victims is work which leaves no one untouched. It is the kind of work that, in many ways, frequently involves therapists personally. It may also be the cause of vehement disagreements about treatments, resulting in fights and splits in treatment teams. The work may end tragically.

I think this also applies to treatment of that other category of people involved in man-made disaster, the perpetrators. However, we know much less about this.

Danieli (1) made a study of the countertransference feelings of about 60 Holocaust survivors' therapists. She came up with, among others, the following themes: guilt, rage, dread and horror, grief and mourning, shame, inability to contain intense emotions, and utilisation of defences such as numbing, denial and avoidance.

It is remarkable to find in her description the way in which therapists are inclined, with regard to Holocaust survivors, to act as their 'parent(s)' or their 'child'.

Acting the part of the parent, in terms of Transactional Analysis, the Negative Nurturing Parent, the therapist especially wants to prevent, out of fear and guilt, the patients from suffering again. The therapist may also move into the position of the Negative Controlling Parent when he/she gets infuriated by the patient because of his/her very obstinate complaints, or because the patient attributes the part of the persecutor (the Nazis) to the therapist.

In terms of Transactional Analysis one may also watch the therapist taking up the Child-part. This is expressed in many ways in the above-mentioned thematical row and the reason behind this is that the therapist wants to behave like a good child, with respect to the parents who have already suffered very much and who have to be spared by all means. Furthermore, the therapist is a fearful child, because he cannot cope with these horrible stories. The therapist is also ashamed because he has not experienced anything of this suffering himself. Moreover, the therapist may act like a strong child that would preferably quickly save its parents by means of its power (and impatience!). Eventually, the therapist may come to look at these helpless, unsavable parents, as being quite tiresome. Also the danger exists that a sadistic child will look for sensational stories that may offer extra suspense: the 'child' in the therapist will continue to ask exaggerated and needless questions about persecution and war stories.

The psychological effects of working with victims are described in a different way by McCann and Pearlman (2). The significance of their account is that because of the material - the patient's state of being traumatised - the therapist risks the danger of becoming traumatised himself. Therapists themselves get nightmares, fearful thoughts, intrusive images and become suspicious towards their fellowmen. These authors think the nature of the material itself is dangerous to several basic securities that the therapist as a human being, has concerning himself and theworld. Under the influence of the powerlessness of the patients the idea arises that having a grip on life is an illusion. In addition, the therapist working with victims may become estranged from his family, his friends and his colleagues, because he is exposed to tales of horror and confonted with a cruel reality.

Perpetrators of violence against their fellowmen are numerous in our world. At first sight, it is remarkable that we do not know much about the psychological effect that treating dangerous criminals, torturers and war criminals of major or minor calibre has upon a therapist. Part of the explanation may be that treatment is often restricted to somatic treatment by a general practitioner, a jail practitioner or an internist; as far as psychological or social guidance is concerned, it is frequently of a psychotechnical or psychosocial nature. From forensic psychiatry we know something of the psychological effect on therapists treating perpetrators. Nevertheless, one might expect more literature on the topic, besides that to do with the treatment method and psychodynamic observations. Treating those who commit incest will, for example, indubitably provoke several reactions from the therapist.

The following may be looked upon as a series of impressions gained over the last 25 years or so. These are mainly related to psychiatric examinations, psychiatric-medical, and social psychiatric contacts, as well as psychotherapeutic treatment. Being a consultant in the field of psychosomatic diseases, and, later on, working for the Jewish community and for victims of World War II, I came into contact with 
many former victims, but also with some excollaborators from World War II. Some had committed quite severe crimes for which they had been punished. In addition, I got in touch with Resistance people who misbehaved after the war as collaborators' campguards, with Dutch ex-soldiers from the war between our country and Indonesia who took part in severe repressive actions against the Indonesian people, with several Jewish people who were able to take revenge after their liberation from the concentration camp. All in all, I reached about 50 male perpetrators, amongst whom there were at least 12 with whom I had a longstanding and intensive contact.

It was striking, but not contradictory to information amassed by others, that in hardly any of the cases was moral need brought up; at any rate, it was not noticeable in the first instance. As Lifton $(3,4)$ remarks about the Nazi doctors, (and as was also observed earlier by a journalistic investigation in Holland on SSmen [Armando and Sleutelaar (5)]), it is the commonness, the triviality, almost the banality, of many of these people which strikes one. In a way, these collaborators seem to feel like the losers in a football match who believe they have only lost because of bad luck or circumstances beyond their control. They felt as if they had been on the right side and had really done a good job.

In this article the point at issue is not a psychological typology of the collaborator, the murderer, or the torturer. My primary issue is the feelings they have as they work with therapists, the feelings which determine and restrict their freedom of action and of treatment. Repeatedly I was asked why I treated this category of people (there is no formal obligation in my case). My answer is that I actually offered some of them further contact out of a kind of benevolent curiosity, when I noticed they were not unwilling to talk. In case of consultations with people who came, hesitatinglymotivated, of their own accord (for instance, people who went to the Indies, some ex-Resistance people who were transformed from prisoner into persecutor, the few Jewish perpetrators, some doctors too), I was more likely to offer further contact. However, I did not force myself upon these people; rather I allowed the contact to proceed almost from session to session with the possibility on their behalf to stop at any moment, unless we had decided on regular treatment after going through some kind of initial discussion. Still, even then continuity remained less guaranteed than is the case with 'regular' therapy. Notwithstanding good contact, the feeling that 'this session might also be the last one', always prevailed. This element came from both sides, from the therapist's as well as from the patient's.

The most positive approach I could manage in the case of the perpetrators was usually, initially no more than that of interested curiosity. I was repeatedly assured by them that they did not sense any condemnation or fear within me, nor anything resembling the cold, objective scientist, but rather they saw me more as being something like a Maigret who interestedly looks for the answer to how something fits into the image he forms of a person.

Many of these people show - and this is common knowledge - a strong sense of disavowal, of denial. They spirited away behind thick walls those mental images and memories, those thoughts which would, if allowed to pervade their humanity, be experienced as a very tragic failure of their existence. They retreated into a kind of superiority: 'I was right, even if what I did then is being looked upon as wrong now'. But sleeplessness, depressive feelings overwhelming one unexpectedly, physical complaints for which no somatic cause can be found, excessive drinking, defective, poor - and time and again failing relationships: this too, often was their destiny.

Against a background of what I would like to call therapeutic, obliging scepticism, treatment appears, however, to be possible after all. People let themselves go, people talked, people seemed to know very well what they did at that time, people underwent confrontations with their denial-mechanisms. Whenever, once in a while, they asked me whether I thought them bad, or whether I thought they should do penance, I was perfectly straightforward: 'I don't approve of those deeds. I do not say I am essentially better than you are. You may not have had complete freedom of choice, but you should look into yourself and make sure whether you are being honest about the (im)possibilities'.

It is of major importance that the therapist dares to account for the personal sympathetic feelings that may occur towards the person facing him. One may enter into his world, into the limitedness of his choice, into the miscarriage of his views on man, into the psychological rightness of the then man who was very wrong ethically. At the same time it is crucially important to that man not to concur in some kind of assumed solidarity - in that case one would come to be an accomplice. On the one hand, we should judge these people, identifying ourselves with them as much as possible. On the other hand, we have to keep our distance and should not join in the 'old-chap' game. In order to relieve their own tension, to avoid exposing nasty feelings of self-reproach and fear, they try to get the therapist to go along with them. This sympathy may occur more easily as the therapist becomes more conscious of his own feelings of aggression, of his own sadism, of his own destructive urges. In every one of us hides a minor fascist that, under the 'right' circumstances, might turn into a major fascist. The client's intuition often leads him to know exactly how the therapist wrestles with his own 'bad' side. The position from which the therapist threatens to slide into a feeling of dislike towards the patient who confronts him with his own shady side and his own unsolved problem, cannot be an easy one. And this gets me to the thematics as Danieli describes them. The therapist's feelings of guilt, rage, horror, the threat of being carried away by intense emotions, by defence mechanisms such as denial and avoidance: they can all 
occur.

With perpetrators we do not usually experience the same kind of appeal for help as with the victims; our fantasies of being able to save someone are less stimulated by the perpetrators than the victims. On the contrary, we are rather keen to play the part of the prosecutor. We clearly feel better and superior and we get angry when the client does not regard us any differently from himself.

We saw the way in which countertransference feelings in the treatment of victims may be arranged in order of Transactional Analysis's views. This may happen here as well. We occupy the position of the Nurturing Parent less often, but all the more often we threaten to end up as the Negative Controlling Parent. We allow ourselves to be guided into this position by feelings that satisfy us because they confirm our notion of being better than the perpetrators are (apparently we need this to protect us against our own evil), our notion of being in the right facing these persistent attempts at self-justification on the part of the patient as a result of the patient's self-deception. And sometimes we feel like a frightened child, unable to cope with these stories, or a child looking for sensation, or a child who feels trapped.

The material that is introduced during the treatment of perpetrators is shocking: the therapist is confronted with the world of evil. In a way he is tempted to become disloyal towards his belief that, in principle, there is a significant human existence in which human dignity and values prevail, and that it is useful to aim at helping establish such a world, if only in a very small way, by treating perpetrators of torture. This may turn the therapist into a sombre man: your partner, your children and your colleagues all notice that for quite a long time after treating perpetrators you do not spontaneously join in the ordinary, nice things anymore. Estrangement threatens to take place. Treatment themes sometimes preoccupy the world of your thoughts. A disturbance of the inner, psychic balance threatens to occur. Basically this is no different from McCann and Pearlman's account of the dangerousness of the material captured within the victim's experiences.

It will be obvious that in this context psychotherapy or, when there is not any mention of long-standing intensive psychotherapy, at any case working with a psychotherapeutic attitude concerning psychiatric and psychological research and advice, is a risky profession. With respect to the profession, as Kohut says (6), a connection between art and psychotherapy is indispensable. The profession demands a certain kind of childlike openness to new experiences by the grace of a (temporary) lapse of psychological buffers both inside and outside. Some kind of 'lying openly' is required. Bion (7) gave a function analysis of the psychotherapist working with (difficult) patients' problems. He uses the notion 'to contain'. The therapist has to be able to contain, to absorb, but also to restrict and restrain; the patient deposits the overwhelming emotional excitement adherent to his problems within the therapist. Winnicot $(8,9)$ uses the concept 'holding environment' with respect to the therapist's position. The therapist has to be capable of enduring the flow of feeling, excitement, mourning and pain. He must innerly transform these and return them digestibly to the patient.

It is common knowledge that it is impossible for patients in treatment - victims as well as perpetrators to get far beyond the therapist's stage. Therefore, the therapist has to expand and re-organise his inner world. Furthermore, I can only briefly indicate the importance for therapists treating victims and perpetrators of trauma, particularly man-made disaster, to protect themselves and at the same time offer optimum treatment conditions, by taking psychohygienic precautions in carrying on their profession. I mention in this connection the importance of good, personal therapy and of good supervision and regular case-discussions with colleagues during which the therapist's own feelings may also be presented for discussion. And eventually there should be professional consideration with respect to the ethical aspects of our functioning.

Fohan Lansen, $M D$, is the Medical Director of Sinai Centrum, the fewish Community Mental Health Services in The Netherlands, PO Box 66, 3800 AB Amersfoort, The Netherlands.

\section{References}

(1) Danieli Y. Psychotherapists' participation in the conspiracy of silence about the Holocaust. Psychoanalytic psychology 1984; 1, 1: 23-42.

(2) McCann L, Pearlman L A. Vicarious traumatization: a framework for understanding the psychological effects of working with victims. Fournal of traumatic stress 1990; 3, 1: 131-149.

(3) Lifton R J. Medicalized killing in Auschwitz. In: Luel S A, Marcus P, eds. Psychoanalytic reflections on the Holocaust: selected essays. New York: Holocaust Awareness Institute, Centre for Judaic Studies, University of Denver and the Ktav Publishing House, 1984.

(4) Lifton R J. The Nazi doctors, medical killing and psychology of genocide. New York: Basic Books, 1986.

(5) Armando, Sleutelaar H. De SS-ers (The SS-men). Amsterdam: De Bezige Bij, 1978.

(6) Kohut H. Childhood experience and creative imagination. In: Ornstein P H, ed. The search for the self, (vol 1). New York: International University Press, 1978.

(7) Grinberg L, Sor D, Tabak de Bianchedi E. Introduction to the work of Bion. Perthshire: Clunie Press, 1975.

(8) Winnicot D W. The maturational processes and the facilitating environment. London: Hogarth Press, 1965.

(9) Winnicot D W. The use of an object and relating through identifications. In: Winnicot D W, ed. Playing and reality. Harmondsworth: Penguin Books, 1974: 101-111. 